\title{
Obituary
}

\section{Enrique de la Garza Toledo - In Memoriam}

\author{
Maria Lorena Cook, Editor, Global Labour Journal
}

We were saddened to learn of the passing of Enrique de la Garza Toledo, a prominent sociologist from Mexico and a member of this journal's Advisory Board, on 24 March 2021. Enrique played a lead role in establishing the field of sociology of work in Latin America. A prolific author, Enrique's research and writing covered a wide array of topics, ranging from studies of the maquiladora sector in Mexico to theorising on such phenomena as "non-standard work" that sought to reflect and understand developments in the region. His edited volume, Tratado Latinoamericano de Sociología del Trabajo (Latin American Treatise on the Sociology of Work, 2000), recorded the rich empirical and theoretical work being produced throughout Latin America and became a touchstone in the field. He was in the process of updating this volume when he died.

I first met Enrique de la Garza in Mexico City in the early 1980s, when he was writing crónicas (chronicles) for a small publication called Información Obrera. These were short narratives of worker resistance and strikes, often accompanied by photos and illustrations and meant to be read by workers themselves at a time when many Mexican workers' movements faced repression. In his later accounts of the evolution of studies of work in Latin America, Enrique would write about the crónica as one of the field's earliest forms.

Enrique's early commitment to tracking and relaying workers' struggles foretold his enduring efforts to address questions of class, capitalism, inequality and injustice through his scholarship and public engagement. His work constantly explored new developments taking place at worksites throughout Mexico, and his curiosity and indefatigable work ethic led him to produce important conceptual and theoretical work as well as detailed empirical descriptions of these developments. He pioneered the use of concepts more suited to the Latin American context, breaking with a tradition of acritical adoption of theoretical categories from the United States and Europe. In particular, he drew on observations from fieldwork to introduce new ways of thinking about informality and precariousness. Some of Enrique's research appeared in this journal: see "Searching for Mexico's Lost Labor Subject: Historical and Biographical Milestones in the Constitution of the Sociology of Work in Mexico" and "Corporatism, Informality and Democracy in the Streets of Mexico City".

In addition to his research contributions to studies of work in Latin America, Enrique also helped to expand the field through networking and institution-building. In the early 1990s he was a founding member of the Latin American Association of Studies of Work (ALAST), which continues to meet and produce an important journal, the Revista Latinoamericana de Estudios del Trabajo (Latin American Journal of Studies of Work). Among other initiatives, Enrique founded the Mexican Association of Studies of Work and the Mexican journal Trabajo, as well as graduate programmes in Social Sciences and Labour Studies at the Universidad Autónoma MetropolitanaIztapalapa in Mexico City, where he was a professor. Enrique's scholarship, teaching and key role in developing programmes and international networks have produced a legacy in the field of sociology of work and in the social sciences in Latin America that will endure for generations to come. 
Enrique was also a generous colleague. He invited me to participate in a number of workshops, publications and conferences, including the founding congress of ALAST, held in Mexico City in 1993. I also had the pleasure of hosting Enrique and his partner, sociologist Marcela Hernández Romo, at Cornell University for a sabbatical. As with many who knew Enrique, I learned a tremendous amount from my exchanges with him, and marvelled at his persistent energy, productivity and keen interest in the world around him. His passing not only leaves a void in our field; he will be missed as a colleague and as a friend. 